\title{
KARAKTERISTIK, MOTIVASI DAN NIAT WISATAWAN SURFING DI PANTAI KECAMATAN KUTA UTARA
}

\author{
Ni Putu Windy Pramita \\ I Wayan Suardana \\ Luh Gede Leli Kusuma Dewi \\ Email : windypramita22@ymail.com \\ PS. S1 Industri Perjalanan Wisata \\ Fakultas Pariwisata UNUD
}

\begin{abstract}
ABSTRACK
Black sandy beach tourist attraction of Kuta Northen region that is Batu Bolong beach and Batu Mejan beach which has potential a beautifull oncean, sunset, sunbathing and surfingthe purpose of this study was to determinethe characteristics, motivasi, and intentions rating surfing at Kuta Northen beach. The method used observation, questionnaires, interviews, literature study, and documentation. 213 respondens rating surfing with quantitative descriptive and regression linier analisys. The result obtained in this study are based on age characteristics surfing travelers will see the most travelers age between 18-29 years, male gender, country of origin Australia, and is a businessman, a master degree educational level, and marital status is not married. Surfing tourist motivation using push and pull factor with the highest scores on the social interaction. And Intention surfing tourist with the highest score there is positive world of mouth with Variabel tourist have the effect of 13,20\% with a probability level of sig. 0,000, the motivation positive and significant efeect on the intention tourist but in small quantities. Therefore to improve the intention tourist come to the beach district of north kuta from the motivation pull and push should also improve the quality of beaches such as keeping the beach becomes the most importans thing that will directly make tourist feel comfortable. advice for managers is to add a lifeguard to keep the beach.
\end{abstract}

Keywords: Characteristic, Motivation, Intention, Tourist, Surfing.

\section{PENDAHULUAN}

Keragaman budaya ini dilatari oleh adanya agama, adat istiadat yang unik, dan kesenian yang dimiliki oleh setiap suku yang ada di Indonesia. Di Samping itu, alamnya yang indah akan memberikan daya tarik tersendiri bagi wisatawan baik itu alam pegunungan (pedesaan), alam bawah laut, mau pun pantai. Pariwisata telah dikembangkan di berbagai provinsi, termasuk salah satunya di Provinsi Bali. Provinsi Bali merupakan salah satu dari 34 provinsi di Indonesia yang terdiri dari Pulau Bali, Pulau Nusa Penida, Nusa Lembongan Ceningan Menjangan dan Nusa Dua yang memiliki wilayah seluas 5.636,66 $\mathrm{Km}^{2}$. Badung merupakan salah satu Kabupaten di Bali yang memiliki berbagai potensi pariwisata, dan hampir seluruh daerahnya telah ditetapkan sebagai kawasan pariwisata, Kabupaten Badung terbagi menjadi 3 (tiga) wilayah pembangunan yaitu: Badung Utara, Badung Tengah, dan Badung Selatan.

Salah satu potensi wisata yang cukup signifikan untuk digali dan dikembangkan yang ada di Kabupaten Badung khususnya di Badung Selatan yaitu daya tarik wisata yang belum dikembangkan secara maksimal adalah daya tarik wisata pantai berpasir hitam di kawasan Kuta Utara yaitu Pantai Batu Bolong dan Pantai Batu Mejan (Echo Beach). Pantaipantai ini memiliki potensi berupa pemandangan laut yang indah, sunset, pasir hitameksotis yang bisa dijadikan sarana berjemur untuk wisatawan, untuk olah raga selancar (surfing) maupun untuk parasailing air. Selain itu di sekitar tepi pantai juga sudah banyak tersedia sarana akomodasi tempat penginapan berupa Hotel dan Villa,serta Restoran yang disediakan untuk wisatawan. 
Potensi ombak yang dimiliki Pantai Batu Bolong dan Pantai Batu Mejan (Echo Beach) menjadi sebuah daya tarik bagi wisatawan, khususnya bagi peselancar. Dari perkembangan wisatawan surfing yang dapat di katakana cukup pesat menjadikan alasan untuk mencari tahu karakteristik, motivasi dan niat wisatawan surfing di pantai kecamatan kuta utara.

\section{METODE}

Terdapat 3 variabel yaitu: karakteristik, motivasi, dan niat wisatawan. Dengan definisi operasioanal untuk karakteristik berdasarkan tourist descriptor yaitu: kategori usia, jenis kelamin, negara asal, jenis pekerjaan, tingkat pendidikan, dan status perkawinan. Berdasarkan motivasi wisatawan sesuai sub variabel push factor dan pull factor, berdasarkan 10 indikator yaitu: escape, relaxation, play, strengthening family bonds, prestise, social interaction, romance, educational opportunity, self- fulfillment dan wish fulfilment, dan full factor memiliki 4 indikator yaitu: location climate access and offordable adventure natural environment. Berdasarkan niat wisatawan terdapat 4 indikator yaitu: loyality to the company/ destination, positive world of mouth, propensity to switch dan complaining. Teknik penentuan sampel adalah purposive sampling dengan jumlah sampel 213 responden. Dalam pengumpulan data digunakan teknik observasi, wawancara, kuesinoer, dokumentasi dan studi pustaka. Teknik analisis data yang digunakan adalah teknik analisis deskriptif kuantitatif dengan penghitungan analisis regresi sederhana serta menggunakan skala likert dalam perhitungan skala sikap wisatawan.

\section{HASIL}

Berdasarkan penyebaran kuisioner terhadap 213 responden dapat diketahui bahwa karakteristik wisatawan kategori usia antara 18-29 tahun terdapat 110 responden atau $(51,6 \%)$. Berdasarkan kategori jenis kelamin laki-laki terdapat 119 responden atau $(55,8 \%)$. Berdasarkan negara asal terdapat 89 responden atau (41,7). Berdasarkan kategori jenis pekerjaan sebagai pengusaha terdapat 54 responden atau $(25,7)$. Berdasarkan kategori tingkat pendidikan magister terdapat 99 responden atau (46,6\%). Dan berdasarkan kategori status perkawinan dengan status belum kawin terdapat 113 responden atau $(62,5 \%)$.

Motivasi yang mendorong (push factor) wisatawan surfing di pantai Kecamatan Kuta Utara dapat dilihat pada Tabel 1.

Tabel 1. Motivasi Yang Mendorong (Push Factor) Wisatawan Surfing di Pantai Kecamatan Kuta Utara

\begin{tabular}{clrc}
\hline No & \multicolumn{1}{c}{ Pernyataan } & $\begin{array}{c}\text { Total } \\
\text { Skor }\end{array}$ & $\begin{array}{c}\text { Rata- } \\
\text { rata }\end{array}$ \\
\hline 1 & $\begin{array}{l}\text { Berinteraksi dengan } \\
\text { masyarakat ataupun } \\
\text { wisatawan lain }\end{array}$ & 956 & 4,50 \\
\hline 2 & $\begin{array}{l}\text { Mengetahui dan } \\
\text { mempelajari hal yang } \\
\text { baru }\end{array}$ & 932 & 4,39 \\
\hline 3 & $\begin{array}{l}\text { Relaksasi atau } \\
\text { mencari ketenangan }\end{array}$ & 903 & 4,25 \\
\hline$\quad$ & & 13,14 \\
\hline \multicolumn{2}{c}{ Total } & 4,38 \\
\hline
\end{tabular}

Sumber: Hasil Penelitian, 2016.

Diketahui dari Tabel 1, motivasi yang mendorong (push factor) wisatawan surfing di pantai Kecamatan Kuta Utara adalah: 1) berinteraksi dengan masyarakat ataupun wisatawan lain dengan skor 956 dan rata-rata 4,50 termasuk kategori sangat setuju. 2) mengetahui dan mempelajari hal yang baru dengan total skor 932 dan rata-rata 4,39 termasuk kategori sangat setuju. 3) relaksasi atau mencari ketenangan dengan total skor 903 dan rata-rata 4,25 termasuk kategori sangat setuju. Motivasi yang menarik (pull factor) wisatawan surfing di pantai Kecamatan Kuta Utara dapat dilihat pada Tabel 2.

Tabel 2. Motivasi Yang Menarik (Pull Factor) Wisatawan Surfing di Pantai Kecamatan Kuta Utara

\begin{tabular}{clcc}
\hline No & Pernyataan & $\begin{array}{c}\text { Total } \\
\text { Skor }\end{array}$ & $\begin{array}{c}\text { Rata- } \\
\text { rata }\end{array}$ \\
\hline 1 & $\begin{array}{l}\text { Akses menuju Pantai } \\
\text { dan kemudahan jalur } \\
\text { transportasi }\end{array}$ & 930 & 4,38 \\
\hline 2 & $\begin{array}{l}\text { Iklim atau suasana di } \\
\text { pantai Kuta Utara }\end{array}$ & 933 & 4,40 \\
\hline & Total & 8,78 \\
\hline Rata-rata & 4,39 \\
\hline
\end{tabular}

Sumber: Hasil Penelitian, 2016. 
Diketahui dari Tabel 2, motivasi yang menarik (pull factor) wisatawan surfing di pantai Kecamatan Kuta Utara adalah 1) akses menuju Pantai dan kemudahan jalur transportasi mendapat total skor 930 dan ratarata 4,38 termasuk kategori sangat setuju. 2) iklim atau suasana di pantai Kuta Utara memperoleh total skor 933 dan rata-rata 4,40 termasuk kategori sangat setuju. Dan niat wisatawan surfing di pantai Kecamatan Kuta Utara dapat dilihat pada Tabel 3.

Tabel 3. Niat Wisatawan Surfing Di Pantai Kecamatan Kuta Utara

\begin{tabular}{clcc}
\hline No & \multicolumn{1}{c}{ Pernyataan } & $\begin{array}{c}\text { Total } \\
\text { Skor }\end{array}$ & $\begin{array}{c}\text { Rata- } \\
\text { rata }\end{array}$ \\
\hline 1 & $\begin{array}{l}\text { Pemberian informasi } \\
\text { positif kepada teman } \\
\text { dan keluarga }\end{array}$ & 1.045 & 4,92 \\
\hline 2 & $\begin{array}{l}\text { Tidak mudah } \\
\text { berpindah ke destinasi } \\
\text { lain }\end{array}$ & 858 & 4,04 \\
\hline & & \\
\hline Total & & 8,96 \\
\hline Rata-rata & 4,48
\end{tabular}

Sumber: Hasil Penelitian, 2016.

Diketahui dari Tabel 3, niat wisatawan surfing di pantai Kecamatan Kuta Utara adalah 1) pemberian informasi positif kepada teman dan keluarga mendapat total skor 1.045 dan rata-rata 4,92 termasuk kategori sangat setuju. 2) tidak mudah berpindah ke destinasi lain memperoleh total skor 858 dan rata-rata 4,04 termasuk kategori setuju.

\section{PEMBAHASAN}

Karakteristik wisatawan surfing yaitu tourist descriptor (Seaton, Bannet, 1996) berdasarkan usia 18-29, jenis kelamin lakilaki, negara asal Negara Australia, jenis pekerjaan sebagai pengusaha, tingkat pendidikan sebagai magister, dan status perkawinan belum kawin.

Motivasi wisatawan surfing menggunakan Dann (1977), Crompton (1979) dalam (Wall \& Mathieson, 2006) yaitu: push factor dan pull factor terdiri dari Escape, Relaxation, Play, Strengthening family bonds, prestise, Social interaction, romance, Educational opportunity, Self-fulfilment, wish fulfillment, Location climate, Access and offordable, adventure dan Natural environment dengan skor tertinggi pada motivasi pendorong (push factor) adalah social interaction, educational opportunity, dan relaxation dan dengan skor tertinggi pada motivasi penarik (pull factor) adalah location climate dan access and offordable.

Niat wisatawan Surfing menggunakan Liu, Furrer dan Sudharshan, (2001) yang terdapat 4 indikator Niat yaitu Loyality to the company / destination, Positive world of mouth, Propensity to switch, dan Complaining dengan skor tertinggi pada positive world of mouth dan propensity to switch.

Hasil ini juga di dukung oleh penelitian yang di lakukan oleh Mai Ngoc Khuong (2014) yang menyatakan bahwa motivasi wisatawan tidak langsung berdampak pada niat wisatawan untuk datang kembali melainkan melalui kepuasan wisatawan tersebut. Selain faktor penarik dan pendorong peningkatan tujuan kepuasan juga di anggap sangat berpengaruh. untuk meningkatkan niat wisatawan datang ke pantai Kecamatan Kuta Utara, campur tangan masyarakat sangat di perlukan, selalu di tegaskan oleh pihak dari desa pengelolaan restoran, villa ataupun homestay di utamakan masyarakat lokal serta tetap menjaga kebudayaan atau kesakralan dari upacara-upacara yang di laksanakan di sekitar pantai yang selalu menjadi momen yang paling di tunggu oleh wisatawan.

\section{SIMPULAN DAN SARAN Simpulan}

Karakteristik wisatawan surfing berdasarkan umur dengan skor tertinggi mengunjungi pantai di Kecamatan Kuta Utara adalah wisatawan yang berusia antara 18-29 tahun, berdasarkan jenis kelamin yang mengunjungi pantai di Kecamatan Kuta Utara rata-rata adalah laki-laki, berdasarkan negara asalnya yang paling banyak mengunjungi pantai di Kecamatan Kuta Utara adalah wisatawan yang berasal dari Australia, selanjutnya berdasarkan jenis pekerjaannya yang paling banyak adalah berprofesi sebagai pengusaha, berdasarkan tingkat pendidikannya yang paling banyak adalah wisatawan dengan gelar magister atau master, kemudian karakteristik yang terakhir berdasarkan status perkawinan yang paling banyak adalah berstatus belum kawin.

Motivasi wisatawan surfing yang datang mengunjungi Pantai di Kecamatan Kuta Utara adalah wisatawan dengan 14 indikator motivasi dan 4 di antaranya dijawab dengan 
skala tidak setuju yaitu motivasi prestise, romance, wish fulfillment, dan adventure, dan motivasi dengan skala sangat setuju, setuju dan cukup setuju adalah motivasi Escape, Relaxation, Play, Strengthening family bonds, Social interaction, Educational opportunity, Self-fulfilment, Location climate, Access and offordable, dan Natural environment. motivasi dengan skor tertinggi 956 yakni: motivasi social interaction atau berinteraksi dengan masyarakat lokal dan wisatawan lain yang ada di pantai.

Niat wisatawan surfing yang datang mengunjungi pantai di Kecamatan Kuta Utara adalah wisatawan dengan 4 indikator Niat yaitu loyality to the company / destination, positive world of mouth, propensity to switch, complaining dan skala jawaban di 4 indikator ini adalah cukup setuju, setuju dan sangat setuju dengan skor tertinggi 1.045 yakni: positive world of mouth atau mau memberikan informasi positif mengenai pantai Kecamatan Kuta Utara dengan kerabat ataupun teman.

\section{Saran}

Untuk keamanan dari pengujung ataupun wisatawan yang datang ke pantai di Kecamatan Kuta Utara perlunya menambah lifeguard untuk mengawasi keamanan pantai.
Menjaga kebersihan yang merupakan salah satu faktor penarik para wisatawan yang berkunjung ke pantai Kecamatan Kuta Utara.

\section{DAFTAR PUSTAKA}

Hsiu-Jung Chou (2013), "Impact of Recreation Experience and Tourism Attractiveness on Tourist Satisfaction and Intention to Revisit-An Example of Kenting National Park in Taiwan"International Journal of Business and Behavioral Sciences,Vol.3 No.11.

Liu, Furrer, Sudharshan (2001), "The Relationships Between Culture and Behavioral Intentions Toward Services" Journal Of Service Research.

Mai Ngoc Khuong, Huynh Thi Thu Ha(2014), "The Influences of Push and Pull Faktors on the International Leisure Tourists' Return Intention to Ho Chi Minh City, Vietnam - A Mediation Analysis of Destination Satisfaction" International Journal of Trade, Economics and Finance, Vol. 5 no. 6.

Seaton, A.V dan Bennet M. 1996. The Marketing Tourism Products: Concepts, Issues and Cases. International Thomson Business Press: London. 